\title{
Development of Numerical Materials Based on Computer Method in IKIP Budi Utomo Malang
}

\author{
Ririn Dwi Agustin ${ }^{1}$, Mika Ambarawati ${ }^{2}$ \\ Department Mathematic Education \\ IKIP Budi Utomo Malang \\ Malang, Indonesia \\ ${ }^{1}$ ririndwiagustin85@gmail.com \\ ${ }^{2}$ Mikaambarawatio88@gmail.com
}

\begin{abstract}
The purpose of this reseach is to (1) compose textbooks of computer-based numerical method in IKIP Budi Utomo Malang, (2) the validity and effectiveness of textbook of computer-based numerical method in IKIP Budi Utomo Malang.

This research uses Research and Development method of Borg and Gall model with the last 4 step deduction, grouped in preliminary stage (petition and problem, information gathering), development stage (product design, design validation, design revision), Phase evaluation (product trial). The trial target of the textbook developed is a student of class of 2014 Mathematics Education Study Program IKIP Budi Utomo Malang. The instrument used in this research is validation sheet filled by validator, and student opinion polls filled out by students after trial textbook.
\end{abstract}

The results of the analysis in the preliminary stage shows that the textbook of numerical methods that exist in IKIP Budi utomo Malang is still very minimal, in the process of learning using only one textbook and that too the book used for the engineering study program. Expert judgments on teaching materials developed in the criterion of the prevalence obtained an average score of 86.80 with a percentage of $86.80 \%$ so that the textbook developed has a validity criterion is very valid. The effectiveness of textbooks developed was seen from the questionnaire of student opinions obtained after trial textbooks obtained an average score of 42 with $87.5 \%$ percentage so that developed textbooks have effective effectiveness criteria.

\section{Keywords-Development of Textbook, Numerical Method,} Computer

\section{INTRODUCTION}

Indonesia today is in dire need of a professional educator in its field. Lecturers who are able to teach and educate the students with good. But in reality, there are still many lecturers who can not be professional in their field. Based on the experience in the field it appears that the lecturers are still less trying to improve the quality of learning. Lecturers still like to use the old way that is, lecture and question and answer duties. This certainly affects the students' difficulties in capturing the material presented. Moreover, many students are still lazy to ask when experiencing difficulties. Students feel embarrassed and scared when later another friend mocks that he is incapable or stupid. As for the lecturers, if no one asks questions about the material that the teacher convey, the lecturer concludes that the students already understand and able to complete the task that will be given. Though the reality is not so.

Mathematics is a subject taught from elementary school (SD) to university (PT), it shows that mathematics has an important role in education. So from the basic to the highest level of mathematics education is always taught and made compulsory lessons. One of the subjects of numerical method is given in Mathematics Education Study Program IKIP Budi Utomo Malang with the aim to prepare or equip students about basic concepts and techniques using numerical methods in solving mathematical problems. In the course of numerical calculation method requires calculating tools such as calculators and computers.

Textbook is one of the things that support the teaching and learning process. In the absence of textbooks, students may find it difficult to understand the material if they rely solely on explanations from lecturers. Meanwhile, according to [1] in the reality of education in the field, we see a lot of education is still using conventional teaching materials, that is ready-to-use teaching materials, live buy, instant and without effort to plan, prepare, and arrange it yourself. Thus, the risks are very likely that the materials they use are not creative, unattractive, monotonous, and not in accordance with the needs of learning. Thus, students are difficult to understand the book in reading, less motivation to learn students. Thus, it is difficult to achieve the optimal learning objectives .

The solution to consider is the use of methodological evidence in the learning process. It is hoped that the students 
can have more opportunities to learn on their own, read the description, and the instructions in the activity sheet, answer the questions and carry out the tasks to be accomplished in each task with the computer based on which MsOffice excel is here.

Difficulty in understanding the concepts and algorithms of numerical method completion resulted in the students spend considerable time to bias master the material well. The use of computers to facilitate the calculation process is not done properly because the students also do not master well the basics of computer programming. The absence of a source book that is used as a reference in the course of Numerical Method of Mathematics Education Study Program IKIP Budi Utomo Malang is in accordance with the syllabus of the lecture becomes the most crucial factor.

Based on the problems that have been mentioned above, it takes the instruction book Computer-Based Numerical Method. The book also uses a language that is easy to understand in terms of mathematical language logic and uses the term commonly used in the student environment. The presentation of the book content is also relevant to the ability of Mathematics Education Study Program IKIP Budi Utomo Malang.

\section{EASE OF USE}

\section{A. Substance Instructional}

Textbooks are well-designed instructional materials in accordance with instructional principles to achieve the learning objectives of a course. Teaching materials are materials or lecture materials are arranged systematically used lecturers and students in the lecture [2]. Teaching materials are independent, meaning that can be studied by students independently because the teaching materials have a structure and a systematic order, namely: a. Describe the instructional objectives to be achieved, b. Motivating students to learn, c. Accommodating student learning difficulties, d. Provide training opportunities for students, e. Provide summary, f. Student oriented individually (learner oriented). A textbook may include instructional guidance, competencies to be achieved, support information, exercises, work instructions may be worksheets, and evaluations [3] Thus can be abstracted that the book as a teaching material is a set of materials arranged systematically so as to create an atmosphere or environment that allows students to learn well. This textbook structure contains the competencies to be achieved, study instructions, supporting information, exercise exercises, and summaries. 1. Lecture Numerical Method Subject Numeric Method is a course that examines various alternative methods available in an attempt to solve the problem of mathematical problems that can not be solved analytically. Method means way, nemerik means number. So literally, numerical methods mean how to count by using numbers.

\section{B. Utilization of Computer as Learning Media}

The term computer (computer) is taken from the Latin computare which means calculate (to compute or to reckon). While [4] states that: The computer is an electronic system for manipulating data quickly and appropriately and designed and organized to automatically receive and store input data, process it and produce output, its work is controlled by programs stored in its storage and the program is known as operating system.

A computer is an electronic device that can receive inputs, and then perform processing (process) to produce output (output) of information quickly through a particular program or application

The rapid development of computers and the number of experiments on computers performed to produce a medium that is able to facilitate teaching and learning activities. Utilization of computer technology has contributed a lot to the learning process is to simplify and clarify the material is so diverse and provide a concrete example, in other words the computer can be utilized as a medium of learning.

The role of computers in education according to Robert Taylor in [5] is divided into 3 parts, namely: the role of computers in education is divided into 3 parts, namely tutor, tool and tutee. As tutors, computers play a role as teachers through computer-assisted teaching approaches. As a tool, computers play a role as a learning tool and as a tutee, computers serve as a way to teach critical thinking. The role of computers in other fields of education can be seen in the Electronic Library (E-Library), Electronic Book (E-Book), ELearning, and others.

Based on the above explanation can be deduced computer as a tool, implies that the computer is a tool in the learning process, while the computer as a tutor means that the computer replaces the role of teachers in teaching, presenting information, test through questions and provide feedback as in the game learning or involving students in simulations or games.

The term used for learning activities that use computers in the learning process is called Computer Based Instruction (CBI) or Computer Based Learning (PBK). In Computer Based Learning (PBK), the computer is used as a tool of individual learning system (individual learning) and apply the principle of learning thorough (mastery learning).

This is in line with what was proposed by Robert Heinich, Molenda, and James D. Russel [2] in which states that "computer system can delivery instruction by allowing them to interact with the lesson programed into the system; this is refered to computer based instruction".

It can be concluded that Computer Based Learning (PBK) is a form of learning that puts the computer as a tool of learning system directly to the students by interacting with subjects that are programmed into the computer system and refers to the principle of learning that was deliberately designed or utilized by teachers and lecturers.

\section{RESEARCH METHODOLOGY}

Research that will be implemented refers to research and development (Research and Development).

The development of this textbook uses the Borg and Gall model with the last 4 step deduction with preliminary stage 
grouping, development stage and evaluation phase so that it presents the following stages [6]

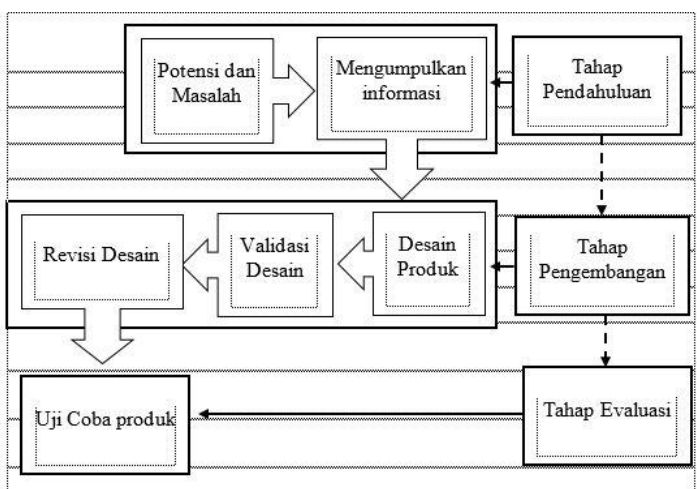

Fig.1. Steps of Use of Research and Development Methods [3]

\section{A. Introduction Phase}

The research that begins by identifying the potentials and problems that exist in Pogram Mathematics Education Studies class of 2014 IKIP Budi Utomo Malang by way of direct observation and observation of data and interviews with lecturer pengampuh and continued by collecting information as a stage in collecting initial data or information that can be used as an ingredient in planning product development that is expected to solve the problem.

\section{B. Development Stage}

Development stage is the process after the introduction phase, based on the findings in the introduction phase it will be developed a textbook that is expected to overcome the existing problems, development studies include: 1) product design 2) Design Validation 3) design revision.

\section{Evaluation Stage}

The evaluation stage is a product trial process conducted to obtain an assessment of the developed learning product and to know the effectiveness of the developed product.

Instrument in this research consist of validation sheet and student opinion questionnaire to the developed textbook.

\section{RESULT AND DISCUSSION}

Early identification has been known that textbooks used by faculty and students are currently less help students in learning because [3] the number is limited So it takes a product in learning that can overcome the problems in the form of textbooks

Based on the student's needs, the researcher develops a computer-based teaching book, the development used is Research and Development. Textbook has been validated by three validator, who is a lecturer of mathematics
IKIP Budi Utomo Malang The validation result from the validator shows a good level of eligibility and teaching textbook can be tested with revision.

Overall, the development of textbooks of computerbased numerical method is declared feasible and can be used in learning indicated with validation results from the validator obtained an average score of 86.80 with the percentage of $86.80 \%$ validation criterion of the first is very valid. So the textbook developed can be said to be valid and feasible. The result of student opinion questionnaire about developed textbook shows average score 41,82 with percentage $87,12 \%$. Based on the average score and the percentage obtained by the textbook developed criteria are very effective. Overall it can be concluded that textbooks of computer-based numerical methods that are well developed, worthy of use, and interesting to learn

\section{CONCLUSION}

Based on the results of research and discussion, it was concluded that the textbook of computer-based numerical method developed by research method

1. The results of the textbook validity test obtained an average score of 86.80 with a percentage of $86.80 \%$ so the textbook developed has a validity criterion is very valid.

2. The results of trial textbooks based on student opinion polls as research targets memproleh average score 42 with $87.5 \%$ percentage so that the developed textbook has effective effectiveness criteria are used in the process of learning mathematics.

3. Based on the results of validation conducted by experts and experimental results of textbooks, textbooks developed have Valid and Effective quality.

4. Textbook is very feasible to be used in the learning process seen from the validation test and questionnaire of student opinion about textbook, hence from that have created a teaching book of computer-based numerk method valid and effective for student of study of mathematics education IKIP Budi Utomo Malang

\section{REFERENCES}

[1] P. A., Panduan Kreatif Membuat Bahan Ajar Inovatif, Jogjakarta: DIVA press, 2012.

[2] Rusman,et al.,, Model Model Pembelajaran Mengembangan Profesionalisme Guru, Depok: Raja Grafindo Persada, 2011.

[3] A. Majid, Perencanaan Pembelajaran (pengembangan Standart Komepetnsi Guru, Bandung: Rosdakara, 2008.

[4] Ririrestiani, "Peranan Komputer dalam Masyarakat," 2012.

[5] Sandres, Pengertian Definisi Komputer Menurut Para Ahli, 2012.

[6] Sugiyono, Metode Penelitian Pendidikan (pendekatan Kuantitaif, Kualitatif, Bandung: Alfabeta, 2013.

[7] Pannen, et al., Konstrukivisme dalam Pembelajaran, Jakarta: PAU-PPAI, 2001. 